JURNAL PENGELOLAAN LABORATORIUM SAINS DAN TEKNOLOGI

ISSN (Online):

Available Online at https://ejournal.unib.ac.id/index.php/labsaintek/index DOI: https://doi.org/10.33369/labsaintek.v1i1.15460

\title{
PERBANDINGAN UNJUK KINERJA BERBAGAI TIPE pH METER DIGITAL DI LABORATORIUM KIMIA
}

\author{
${ }^{1}$ Devirizanty, ${ }^{2}$ Susianan Nurmalawati, ${ }^{3}$ Candra Hartanto \\ ${ }^{1,2,3}$ PLP Laboratorium Kimia, Fakultas Matematika dan Ilmu Pengetahuan Alam, \\ Universitas Bengkulu
}

Korespondensi: devirizanti_unib@yahoo.com

\begin{abstract}
Abstrak
Laboratorium Kimia FMIPA UNIB adalah laboratorium yang berkecimpung dalam hal pelayanan pendidikan, penelitian, analisa dan pengabdian kepada masyarakat. Dalam bidang kimia, pengukuran analitik memiliki peranan yang sangat penting. Tujuan dari pengukuran analitik ini adalah untuk menentukan nilai sebenarnya dari suatu parameter kuantitas kimia, contohnya seperti: konsentrasi, $\mathrm{pH}$, dan lain-lain. Pengukuran analitik ini dapat menggunakan metode konvensional maupun modern, baik secara kualitatif maupun kuantitatif.. Dalam setiap pengukuran analitik akan sangat dipengaruhi pengerjaan prosedur yang baik dan benar dan kompetensi dari analis serta pengguna lainnya. Dimana jika peralatan yang dipakai valid dan akurat serta dikerjakan oleh personil yang kompetens maka akan dapat memberikan kontribusi terhadap hasil pengukuran. Setelah dilakukan uji akurasi, presisi dan cek antara pada penelitian ini menyatakan bahwa ketiga jenis Ph Meter yang yang ada di Laboratorium Kimia yaitu pH meter type PH-108 merck ATC, pH meter HI98107 merck Hanna dan pH meter HI 5521/HI 5522 merck Hanna, memiliki unjuk kinerja yang bagus dan akurat, sehingga masih layak dipakai untuk pengujian, praktikum dan layanan pelanggan.
\end{abstract}

Kata Kunci: bidang kimia, pH meter, pengukuran

\section{Abstract}

Chemistry Laboratory of Science Faculty, Bengkulu University is a laboratory that is engaged in education, research, analysis and community service. In chemistry study, analytical measurements have a very important role. The purpose of this analytical measurement is to determine the true value of a chemical quantity parameter, for example, such as : concentration, $\mathrm{pH}$, and others. This analytical measurement can use conventional and modern methods, both qualitatively and quantitatively. In each analytic measurement, it will be strongly influenced by proper and correct procedure work and the competence of analysts and other users. Only if the equipment used is valid and accurate and done by competent personnel, the result will be accounted for. After testing the accuracy, precision and intermediate checks in this research, it is obtained that the three types of $\mathrm{Ph}$ Meters in the Chemistry Laboratory were $\mathrm{pH}$ meter type PH-108 merck ATC, pH meter HI98107 merck Hanna and pH meter HI 5521 / HI 5522 merck Hanna, has a good and accurate performance, so it is still suitable for testing, practicum and customer service.

Keywords: chemistry, $\mathrm{pH}$ meter, measurement 


\section{PENDAHULUAN}

Peranan Laboratorium dalam Perguruan Tinggi adalah sebagai wadah bagi mahasiswa, dan dosen mengembangkan dan melakukan penelitian yang bermanfaat bagi dunia pendidikan. Laboratorium sebagai wadah penelitian memfasilitasi instrumen, alat, dan bahan yang digunakan bagi dosen dan mahasiswa. Instrumentasi sebagai alat ukur yang hampir digunakan dalam semua kegiatan di laboratorium memerlukan perawatan dan pengecekan secara berkala untuk mengetahui akurat atau tidak hasil data yang didapat. Karena itulah perlu dilakukan pengecekan peralatan dengan melakukan uji efektivitas alat tersebut. Pemakaian instrumen laboratorium yang memperhatikan standar operasi alat sangat diperlukan. Standar Pemakaian alat sendiri telah diterapkan melalui adanya pengisian buku kontrol alat, pembersihan instrumen setelah digunakan, penempatan alat instrument dan SOP peralatan yang ditempatkan ditempat yang mudah dibaca dan dipahami pengguna.

Peran Pranata Laboratorium Pendidikan adalah mengawasi dan memberikan supervisi penggunaan instrumen bagi mahasiswa. Tugas Pranata Laboratorium itu sendiri adalah menyampaikan cara pemakaian kepada peserta didik dan memberikan bantuan pemilihan alat yang baik dan berakurasi tinggi untuk dapat digunakan dalam penelitiannya.

Salah satu alat yang akan dikaji saat ini adalah $\mathrm{pH}$ meter. $\mathrm{pH}$ meter adalah alat untuk mengukur keasaman atau basa suatu larutan. Ada beberapa type $\mathrm{pH}$ meter yang dimiliki laboratorium kimia yaitu type PH108, type HI98107 dan HI 5521/HI 5522.

Selama ini hasil pengukuran berbagai macam larutan dengan menggunakan berbagai macam type $\mathrm{pH}$ meter tersebut memberikan hasil yang berbeda-beda. Perbedaan hasil pengukuran inilah yang mendorong kami untuk melakukan uji presisi dan akurasi dari masing-masing alat yang sudah melalui kalibrasi yang didapat dari larutan standar $\mathrm{pH} 4,01,7,01$ dan 10,01.

Hasil Pembacaaan dengan rentang $\mathrm{pH}$ yang berbeda ini dicatat dan dikumpulkan kemudian dilakukan pengolahan data secara statistik untuk mendapatkan pHmeter yang terstandarisasi dengan tepat, sehingga hasil yang didapat lebih akurat.

\section{METODE PENELITIAN \\ Model Penelitian}

Penelitian ini merupakan jenis penelitian kuantitatif merupakan salah satu jenis penelitian yang spesifikasinya adalah sistematis, terencana, dan terstruktur dengan jelas sejak awal hingga pembuatan desain penelitiannya. Definisi lain menyebutkan penelitian kuantitatif adalah penelitian yang banyak menuntut penggunaan angka, mulai dari pengumpulan data, penafsiran terhadap data tersebut serta penampilan dari hasilnya. Demikian pula pada tahap kesimpulan penelitian akan lebih baik bila disertai dengan gambar, tabel, grafik, atau tampilan lainnya. Menurut Sugiyono, metode penelitian kuantitatif dapat diartikan sebagai metode penelitian yang berlandaskan pada filsafat positifisme, digunakan untuk meneliti pada populasi atau sampel tertentu. Teknik pengambilan sampel pada umumnya dilakukan secara random, pengumpulan data menggunakan instrumen penelitian, analisis data bersifat kuantitatif/statistik dengan tujuan untuk menguji hipotesis yang telah ditetapkan (Sugiyono, 2012:7).

Penelitian ini bertujuan mendapatkan $\mathrm{pH}$ meter digital dengan tipe dan merek apapun yang terstandarisasi dengan tepat dan benar sehingga dapat digunakan utnuk melakukan pengukuran baik sampel maupun larutan uji dengan hasil yang akurat dan dapat dipublikasikan secara luas. 


\section{Prosedur Penelitian}

Prosedur penelitian menggunakan metode kuantitatif adalah suatu proses menemukan pengetahuan yang menggunakan data berupa angka sebagai alat menganalisa keterangan mengenai apa yang ingin diketahui (kasiram (2008: 149) dalam bukunya Metodologi penelitian Kualitatif dan kuantitatif).

\section{Bahan dan Alat}

Bahan yang digunakan adalah:

1. Larutan Buffer $\mathrm{pH} 4.01$

2. Larutan Buffer $\mathrm{pH} 7.01$

3. Larutan Buffer $\mathrm{pH} 10.01$

4. Aquadest

Alat yang digunakan adalah:

5. Magnetic Stirrer

6. Gelas piala $100 \mathrm{ml}$

7. Botol semprot $250 \mathrm{ml}$

\section{Prosedur Penelitian}

Kalibrasi pH

- Masuk dalam mode kalibrasi

- Tempatkan elektroda ke dalam buffer kalibrasi pertama.

- Jika melakukan kalibrasi dua titik, gunakan buffer pH 7,01 terlebih dahulu, tunggu sampai dilayar akan tampil $\mathrm{pH} 7,01$

- Lalu lanjutkan kalibrasi dengan menggunakan $\mathrm{pH}$ 4,01 atau $\mathrm{pH}$ 10,01 dan tunggu sampai di layar akan tampil $\mathrm{pH}$ yang dipakai 4,01 atau 10,01,maka $\mathrm{pH}$ meter siap untuk digunakan.

\section{Pengukuran pH}

- $\quad$ Pastikan $\mathrm{pH}$ meter telah dikalibrasi sebelum digunakan

- Jika elektroda kering, rendam dalam larutan penyimpanan HI70300 selama 30 menit untuk mengaktifkannya kembali.

- Celupkan elektroda ke dalam sampel yang akan diuji sambil mengaduknya dengan pelan.

- Tunggu sampai indikator stabilitas pada LCD menghilang LCD menampilkan nilai $\mathrm{pH}$ (dikompensasi secara atomatis untuk suhu) pada LCD primer, sedangkan LCD sekunder menentukan suhu sampel jika pengukuran dilakukan dalam sampel yang berbeda secara berturut-turut.

- Bilas ujung elektroda secara menyeluruh untuk menghilangkan kontaminasi silang. Setelah dibersihkan, bilas ujung elektroda dengan air deionisasi dan beberapa sampel yang akan diukur

\section{Tempat dan Waktu Penelitian}

Penelitian ini dilakukan di laboratorium kimia (divisi Kimia dasar) FMIPA Universitas Bengkulu Juni-Desember 2020

\section{Subyek dan Obyek penelitian}

Obyek penelitian ini adalah tiga jenis $\mathrm{pH}$ meter yang berbeda type di Laboratorium Kimia FMIPA Universitas Bengkulu. 


\section{Teknik Pengumpulan Data}

Teknik pengumpulan data yang digunakan dalam penelitian ini adalah Kuantitatif. Metode observasi dilakukan dengan cara pembacaan angka yang ditampilkan pada layar $\mathrm{pH}$ meter yang digunakan.

\section{Teknik Analisis Data}

Teknik analisis data penelitian ini menggunakan deskriptif kuantitatif. Deskriptif kuantitatif adalah statistik yang digunakan untuk menganalisis data dengan cara mendiskripsikan atau menggambarkan data yang terkumpul sebagaimana adanya (Sugiyono, 2006).

\section{HASIL DAN PEMBAHASAN Hasil Penelitian}

\section{pH meter Hanna type HI5522}

\begin{tabular}{|c|c|c|c|c|c|c|c|c|}
\hline No & Stnadart pH & $\begin{array}{c}\text { Tanpa } \\
\text { pembacaan }\end{array}$ & Pembacaan & Koreksi & Standar pH & $\begin{array}{c}\text { Tanpa } \\
\text { pembacaan }\end{array}$ & Pembacaan & Koreksi \\
\hline 1 & 4,0000 & 0,0000 & 4,0000 & 0,0000 & 7,0000 & 0,0000 & 7,0000 & 0,0000 \\
\hline 2 & 4,0000 & 0,0000 & 4,0000 & 0,0000 & 7,0000 & 0,0000 & 6,9900 & 0,0100 \\
\hline 3 & 4,0000 & 0,0000 & 4,0000 & 0,0000 & 7,0000 & 0,0000 & 6,9800 & 0,0200 \\
\hline 4 & 4,0000 & 0,0000 & 4,0000 & 0,0000 & 7,0000 & 0,0000 & 6,9800 & 0,0200 \\
\hline 5 & 4,0000 & 0,0000 & 3,9900 & 0,0100 & 7,0000 & 0,0000 & 7,0000 & 0,0000 \\
\hline 6 & 4,0000 & 0,0000 & 3,9900 & 0,0100 & 7,0000 & 0,0000 & 7,0000 & 0,0000 \\
\hline 7 & 4,0000 & 0,0000 & 3,9900 & 0,0100 & 7,0000 & 0,0000 & 6,9800 & 0,0200 \\
\hline 8 & 4,0000 & 0,0000 & 4,0000 & 0,0000 & 7,0000 & 0,0000 & 6,9900 & 0,0100 \\
\hline 9 & 4,0000 & 0,0000 & 4,0000 & 0,0000 & 7,0000 & 0,0000 & 7,0000 & 0,0000 \\
\hline 10 & 4,0000 & 0,0000 & 4,0000 & 0,0000 & 7,0000 & 0,0000 & 7,0000 & 0,0000 \\
\hline \multicolumn{2}{|r|}{ Standar Deviasi } & \multicolumn{3}{|c|}{0,0048} & Standar Deviasi & \multicolumn{3}{|c|}{0,0092} \\
\hline \multicolumn{2}{|r|}{ Koreksi maksimal } & \multicolumn{3}{|c|}{$-0,0100$} & Koreksi maksimal & \multicolumn{3}{|c|}{$-0,0200$} \\
\hline \multicolumn{2}{|r|}{ Standar Deviasi Maksimal } & \multicolumn{7}{|c|}{0,0092} \\
\hline \multicolumn{2}{|r|}{ Ketidakpastian std (Ut) } & \multicolumn{7}{|c|}{0,0029} \\
\hline \multicolumn{2}{|r|}{ Nilai Diskriminasi } & \multicolumn{7}{|c|}{0,53} \\
\hline \multicolumn{2}{|r|}{ Evaluasi } & \multicolumn{7}{|c|}{ Kinerja Bagus } \\
\hline
\end{tabular}

\begin{tabular}{|l|c|}
\hline \multicolumn{1}{|c|}{ Nilai Diskriminasi } & Status $\mathbf{p H}$ meter \\
\hline $\mathrm{SD} \mathrm{BM}<2 \times \mathrm{SD} 1 / 2$ & Kinerja bagus \\
\hline $2 \leq \mathrm{SD} \mathrm{BM}<3 \times$ SD $1 / 2$ & Kinerja cukup bagus \\
\hline $3 \leq \mathrm{SD} \mathrm{BM}<5 \times$ SD $1 / 2$ & Kinerja diterima dan segera dilakukan perbaikan \\
\hline $5 \leq \mathrm{SD} \mathrm{BM}<7 \times \mathrm{SD} 1 / 2$ & Kinerja buruk dan diharuskan perbaikan \\
\hline $7 \leq \mathrm{SD} \mathrm{BM}<10 \times$ SD $1 / 2$ & Kinerja sangat buruk \\
\hline $\mathrm{SD} \mathrm{BM}$ & Standar Deviasi pada kapasitas beban maksimum \\
\hline $\mathrm{SD} 1 / 2$ & Standar Deviasi pada kapasitas $1 / 2$ maksimum \\
\hline
\end{tabular}




\section{1.pH meter Hanna HI98107}

\begin{tabular}{|c|c|c|c|c|c|c|c|c|}
\hline No & Standar pH & $\begin{array}{c}\text { Tanpa } \\
\text { pembacaan }\end{array}$ & Pembacaan & Koreksi & Standar pH & $\begin{array}{c}\text { Tanpa } \\
\text { pembacaan }\end{array}$ & Pembacaan & Koreksi \\
\hline 1 & 4,00 & 0,00 & 4,02 & $-0,02$ & 7,00 & 0,00 & 6,99 & 0,01 \\
\hline 2 & 4,00 & 0,00 & 4,02 & $-0,02$ & 7,00 & 0,00 & 6,99 & 0,01 \\
\hline 3 & 4,00 & 0,00 & 4,00 & 0,00 & 7,00 & 0,00 & 7,01 & $-0,01$ \\
\hline 4 & 4,00 & 0,00 & 4,01 & $-0,01$ & 7,00 & 0,00 & 7,01 & $-0,01$ \\
\hline 5 & 4,00 & 0,00 & 4,00 & 0,00 & 7,00 & 0,00 & 7,02 & $-0,02$ \\
\hline 6 & 4,00 & 0,00 & 4,02 & $-0,02$ & 7,00 & 0,00 & 7,00 & 0,00 \\
\hline 7 & 4,00 & 0,00 & 4,00 & 0,00 & 7,00 & 0,00 & 7,01 & $-0,01$ \\
\hline 8 & 4,00 & 0,00 & 4,00 & 0,00 & 7,00 & 0,00 & 7,02 & $-0,02$ \\
\hline 9 & 4,00 & 0,00 & 4,00 & 0,00 & 7,00 & 0,00 & 7,02 & $-0,02$ \\
\hline 10 & 4,00 & 0,00 & 4,02 & $-0,02$ & 7,00 & 0,00 & 7,02 & $-0,02$ \\
\hline \multicolumn{2}{|r|}{ Standar Deviasi } & \multicolumn{3}{|c|}{0,0099} & Standar Deviasi & \multicolumn{3}{|c|}{0,0120} \\
\hline \multicolumn{2}{|r|}{ Koreksi maksimal } & \multicolumn{3}{|c|}{0,0000} & Koreksi maksimal & \multicolumn{3}{|c|}{$-0,0100$} \\
\hline \multicolumn{2}{|r|}{ Standar Deviasi Maksimal } & \multicolumn{7}{|c|}{0,0120} \\
\hline \multicolumn{2}{|r|}{ Ketidakpastian std (Ut) } & \multicolumn{7}{|c|}{0,0038} \\
\hline \multicolumn{2}{|r|}{ Nilai Diskriminasi } & \multicolumn{7}{|c|}{0,83} \\
\hline \multicolumn{2}{|r|}{ Evaluasi } & \multicolumn{7}{|c|}{ Kinerja Bagus } \\
\hline
\end{tabular}

\begin{tabular}{|l|c|}
\hline \multicolumn{1}{|c|}{ Nilai Diskriminasi } & Status $\mathrm{pH}$ meter \\
\hline $\mathrm{SD} \mathrm{BM}<2 \times \mathrm{SD} 1 / 2$ & Kinerja bagus \\
\hline $2 \leq \mathrm{SD} \mathrm{BM}<3 \times \mathrm{SD} 1 / 2$ & Kinerja cukup bagus \\
\hline $3 \leq \mathrm{SD} \mathrm{BM}<5 \times \mathrm{SD} 1 / 2$ & Kinerja diterima dan segera dilakukan perbaikan \\
\hline $5 \leq \mathrm{SD} \mathrm{BM}<7 \times \mathrm{SD} 1 / 2$ & Kinerja buruk dan diharuskan perbaikan \\
\hline $7 \leq \mathrm{SD} \mathrm{BM}<10 \times$ SD $1 / 2$ & Kinerja sangat buruk \\
\hline SD BM & Standar Deviasi pada kapasitas beban maksimum \\
\hline SD $1 / 2$ & Standar Deviasi pada kapasitas $1 / 2$ maksimum \\
\hline
\end{tabular}

\section{pH meter ATC 108}




\begin{tabular}{|c|c|c|c|c|c|c|c|c|}
\hline No & Standar pH & $\begin{array}{c}\text { Tanpa } \\
\text { pembacaan }\end{array}$ & Pembacaan & Koreksi & Standar pH & $\begin{array}{c}\text { Tanpa } \\
\text { pembacaan }\end{array}$ & Pembacaan & Koreksi \\
\hline 1 & 4,00 & 0,00 & 4,02 & $-0,02$ & 7,00 & 0,00 & 7,03 & $-0,03$ \\
\hline 2 & 4,00 & 0,00 & 4,02 & $-0,02$ & 7,00 & 0,00 & 7,03 & $-0,03$ \\
\hline 3 & 4,00 & 0,00 & 4,02 & \begin{tabular}{l|l|}
$-0,02$ \\
\end{tabular} & 7,00 & 0,00 & 7,03 & $-0,03$ \\
\hline 4 & 4,00 & 0,00 & 4,03 & $-0,03$ & 7,00 & 0,00 & 7,03 & $-0,03$ \\
\hline 5 & 4,00 & 0,00 & 4,03 & \begin{tabular}{l|l|}
$-0,03$ \\
\end{tabular} & 7,00 & 0,00 & 7,03 & $-0,03$ \\
\hline 6 & 4,00 & 0,00 & 4,02 & \begin{tabular}{l|l|}
$-0,02$ \\
\end{tabular} & 7,00 & 0,00 & 7,04 & $-0,04$ \\
\hline 7 & 4,00 & 0,00 & 4,03 & $-0,03$ & 7,00 & 0,00 & 7,03 & $-0,03$ \\
\hline 8 & 4,00 & 0,00 & 4,03 & $-0,03$ & 7,00 & 0,00 & 7,03 & $-0,03$ \\
\hline 9 & 4,00 & 0,00 & 4,03 & $-0,03$ & 7,00 & 0,00 & 7,03 & $-0,03$ \\
\hline 10 & 4,00 & 0,00 & 4,03 & $-0,03$ & 7,00 & 0,00 & 7,03 & $-0,03$ \\
\hline \multicolumn{2}{|r|}{ Standar Deviasi } & \multicolumn{3}{|c|}{0,0052} & Standar Deviasi & \multicolumn{3}{|c|}{0,0032} \\
\hline \multicolumn{2}{|r|}{ Koreksi maksimal } & \multicolumn{3}{|c|}{0,0200} & Koreksi maksimal & \multicolumn{3}{|c|}{0,0300} \\
\hline \multicolumn{2}{|r|}{ Standar Deviasi Maksimal } & \multicolumn{7}{|c|}{0,0052} \\
\hline \multicolumn{2}{|r|}{ Ketidakpastian std (Ut) } & \multicolumn{7}{|c|}{0,0016} \\
\hline \multicolumn{2}{|r|}{ Nilai Diskriminasi } & \multicolumn{7}{|c|}{1,63} \\
\hline \multicolumn{2}{|r|}{ Evaluasi } & \multicolumn{7}{|c|}{ Kinerja Bagus } \\
\hline
\end{tabular}

\begin{tabular}{|l|c|}
\hline \multicolumn{1}{|c|}{ Nilai Diskriminasi } & Status $\mathbf{p H}$ meter \\
\hline SD BM $<2 \times$ SD $1 / 2$ & Kinerja bagus \\
\hline $2 \leq$ SD BM $<3 \times$ SD $1 / 2$ & Kinerja cukup bagus \\
\hline $3 \leq$ SD BM $<5 \times$ SD $1 / 2$ & Kinerja diterima dan segera dilakukan perbaikan \\
\hline $5 \leq$ SD BM $<7 \times$ SD $1 / 2$ & Kinerja buruk dan diharuskan perbaikan \\
\hline $7 \leq$ SD BM $<10 \times$ SD $1 / 2$ & Kinerja sangat buruk \\
\hline SD BM & Standar Deviasi pada kapasitas beban maksimum \\
\hline SD $1 / 2$ & Standar Deviasi pada kapasitas $1 / 2$ maksimum \\
\hline
\end{tabular}

Dari hasil penelitian ini ternyata kinerja dari tiga jenis pH meter yaitu Hanna HI 5522, HI98107, dan ATC 108 mempunyai unjuk kinerja yang bagus, sehingga masih layak untuk dipakai dalam kegiatan pengujian, praktikum, penelitian dan layanan pelanggan di Laboratorium Kimia FMIPA UNIB.

Analisa Kuantitatif

Data - data di atas kemudian di rangkum dalam satu grafik yang menggambarkan kinerja dari masing-masing tipe $\mathrm{pH}$ meter.

Gambar 6 : Tabel Unjuk Kinerja Dari Tiga Tipe pH Meter

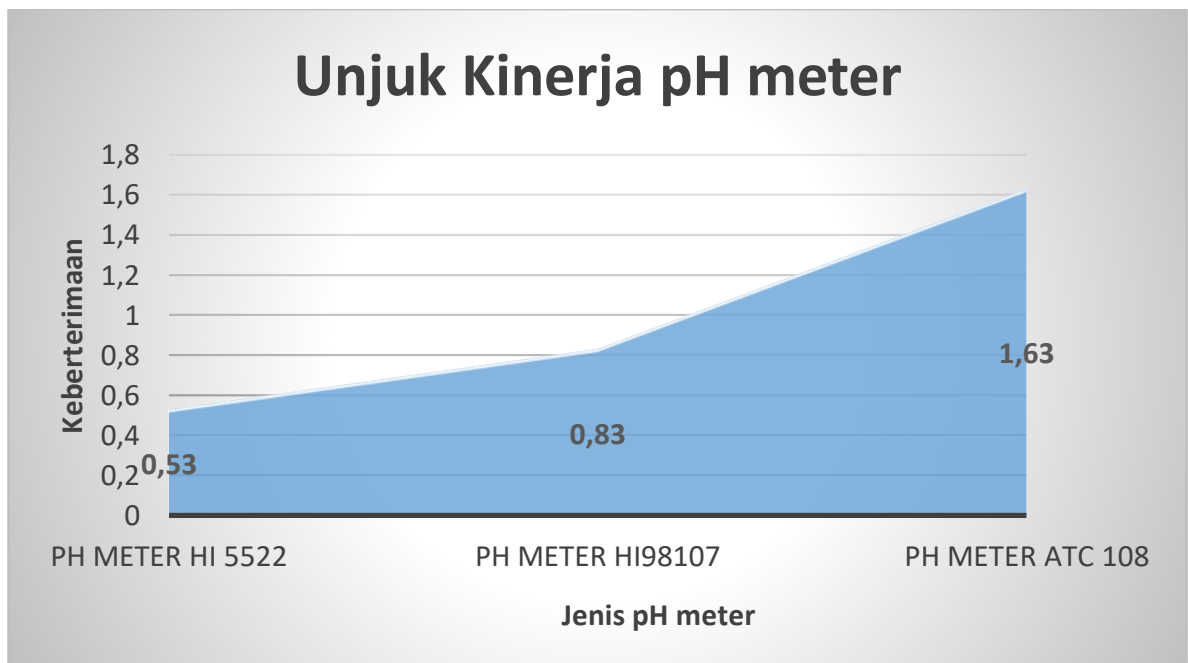

Dari grafik di atas terlihat bahwa ketiga tipe $\mathrm{pH}$ meter menunjukkan unjuk kinerja yang berbeda beda, tapi ketiga $\mathrm{pH}$ meter masih berada pada batas keberterimaan yang dipersyaratkan dalam artian unjuk kinerja bagus, berikut tabel nilai dan tabel keberterimaan yang dipersyaratakan dapat dilihat pada gambar 3 dan gambar 4 di bawah ini.4 
Gambar 7 : Tabel Nilai Diskriminasi dari Ketiga PH meter

\begin{tabular}{|l|c|}
\hline \multicolumn{1}{|c|}{ Tipe pH meter } & Nilai Diskriminasi \\
\hline pH meter HI 5522 & 0,53 \\
\hline pH meter HI98107 & 0,83 \\
\hline pH meter ATC 108 & 1,63 \\
\hline
\end{tabular}

Gambar 8 : Tabel Standar Batas Keberterimaan

\begin{tabular}{|l|c|}
\hline \multicolumn{1}{|c|}{ Nilai Diskriminasi } & Status pH meter \\
\hline SD BM $<2 \times$ SD $1 / 2$ & Kinerja bagus \\
\hline $2 \leq \mathrm{SD} \mathrm{BM}<3 \times$ SD $1 / 2$ & Kinerja cukup bagus \\
\hline $3 \leq \mathrm{SD} \mathrm{BM}<5 \times \mathrm{SD} 1 / 2$ & Kinerja diterima dan segera dilakukan perbaikan \\
\hline $5 \leq \mathrm{SD} \mathrm{BM}<7 \times \mathrm{SD} 1 / 2$ & Kinerja buruk dan diharuskan perbaikan \\
\hline $7 \leq \mathrm{SD} \mathrm{BM}<10 \times \mathrm{SD} 1 / 2$ & Kinerja sangat buruk \\
\hline $\mathrm{SD} \mathrm{BM}$ & Standar Deviasi pada kapasitas beban maksimum \\
\hline SD $1 / 2$ & Standar Deviasi pada kapasitas $1 / 2$ maksimum \\
\hline
\end{tabular}

Dari hasil penelitian ini ternayata kinerja dari tiga jenis $\mathrm{pH}$ meter yaitu Hanna HI 5522, HI98107, dan ATC 108 mempunyai unjuk kinerja yang bagus, sehingga masih layak untuk dipakai dalam kegiatan pengujian, praktikum, penelitian dan layanan pelanggan di Laboratorium Kimia FMIPA UNIB.

\section{Pembahasan Penelitian}

Dilihat dari hasil pengolahan data di atas ternyata dari ketiga jenis $\mathrm{Ph}$ meter yang terdapat Di Laboratorium Kimia FMIPA UNIB menunjukkan kinerja yang cukup bagus dan ketiga-tiganya masih layak dipakai untuk melakukan kegiatan pengujian, penelitian, praktikum dan layanan pelanggan. Dari hasil pengukuran berbagai tipe $\mathrm{pH}$ meter yang ada di laboratorium kimia yang distandarisasi dengan menggunakan larutan standar yang sesuai dengan prosedur SNI. Sesuai dengan hasil pengukuran yang masih dapat ditoleransi sampai rentang range $0,01-0,1$, artinya pengukuran akan akurat jika dilakukan standarisasi yang benar dan tepat sesuai dengan prosedur SNI.

Sebelum melakukan pengukuran $\mathrm{pH}$ meter digital dengan berbagai tipe dan merek tersebut harus dilakukan standarisasi terlebih dahulu. Standarisasi dapat dilakukan dengan lartuan standart Buffer $\mathrm{pH}$ 4, 7 dan 10.

Jika prosedur ini telah dilakukan maka dapat dipastikan pengukuran $\mathrm{pH}$ akan mendapatkan data yang valid dan akurat.

Setelah semua type $\mathrm{pH}$ dilakukan standarisasi dengan benar dan tepat selanjutnya dilakukan pengukuran terhadap suatu larutan yang juga sudah diketahui $\mathrm{pH}$ nya secara tepat dalam hal ini di pakai larutan Buffer $\mathrm{pH} 4$ produksi Merck.

\section{KESIMPULAN DAN SARAN \\ Kesimpulan}

Setelah dilakukan penelitian tentang $\mathrm{pH}$ ini, dapat ditarik kesimpulan bahwa jika kita akan melakukan pengukuran dengan menggunakan peralatan $\mathrm{pH}$ Meter Digital dengan tipe dan merek apapun juga maka sebaiknya harus melakukan standarisasi dulu dengan larutan standart yang sudah tersedia dan mepunyai sertifikat RCM atau pun dengan larutan standar yag dibuat sendiri sesuai SNI.Kalau peralatan $\mathrm{pH}$ meter sudah ditandarisasi maka siap untuk melakukan pengukuran pada sampel, sehingga hasil yang akan didapat pasti lebih akurat. 
Standarisasi wajib dilakukan setiap kali akan melakukan pengukuran untuk menjaga hasil yang diperoleh.

Perhatikan masa kadaluarsa dari larutan standart yang akan dipakai karena hal ini ternyata juga memepengaruhi hasil pengukuran jika larutan standart yang di pakai sudah kadaluarsa.

Larutan standart yang dibuat sendiri sesuai prosedur SNI dapat dipergunakan untuk semua tipe $\mathrm{pH}$ meter, asalkan proses pengerjaannya tepat dan benar.

\section{Saran}

Dalam penelitian ini penulis hanya dapat menyarankan bahwa untuk pengukuran dengan menggunakan peralatan $\mathrm{pH}$ Meter digital dengan type dan merek apapun sebaiknya harus diperhatikan .

1. Larutan standart harus dibuat dengan seteliti mungkin dan sesuai dengan prosedur SNI.

2. Larutan standar yang tersedia apakah masih layak pakai atau tidak, dalam artian sudah kadaluarsa untuk larutan yang dibuat sendiri dapat diketahui dengan timbulnya endapat, larutan menjadi keruh atau bahkan berubah warna, untuk larutan standar yang dari pabrik dapat dilihat pada kemasan botolnya.

3. Cara standarisasi harus disesuaikan dengan metoda yang terdapat pada petunjuk masing-masing prosedur yang menyertai peralatan.

4. Cara penyimpanan peralatan harus sesuai dengan prosedur nya, seperti harus memperhatikan suhu dan kelembaban probe,termasuk larutan yang dipakai untuk perendaman probe jika $\mathrm{pH}$ meter memnggunakan probe.

5. Yang terpenting lakukan cek antara terhadap peralatan $\mathrm{pH}$ meter paling tidak enam bulan sekali untuk mengetahui apakah peralatan masih layak pakai atau tidak.

\section{UCAPAN TERIMA KASIH}

Penulis mengucapkan terima kasih kepada :

1. Pimpinan dan seluruh staff LPPM Universitas Bengkulu yang telah memberikan dukungan dalam penelitian ini .

2. Kepala Laboratorium kimia FMIPA Universitas Bengkulu atas sarana dan prasarana yang disediakan selama penelitian

3. Dan kepada semua pihak yang telah membantu dalam terlaksananya penelitian ini.

\section{DAFTAR PUSTAKA}

Abdul Rohman. 2016. Validasi dan Penjaminan Mutu Metoda Analisis Kimia. Yogyakarta : Penerbit Gadjah Mada University Press.

Anwar Hadi. 2018. Persyaratan Umum Kompetensi Laboratorium Pengujian \& Laboratorium Kalibrasi. Jakarta : Penerbit PT Gramedia Pustaka Utama.

Johari, J.M.C. dan M. Rachmawati. 2004. Kimia SMA untuk kelas XI. Jakarta : PT Esis. Margono, 1977. Kimia untuk SMA. Surakarta : Widya Duta.

.Nur'aini, Dewi Nur dan Sabar Cahyono. -. Simpati Kimia Semester 2 Kelas XI. Surakarta : CV. Grahadi.

Purba, Michael. 2004. Kimia untuk SMA Kelas 2B. Jakarta : Erlangga

SNI 6989.11 : 2004 Cara Uji Derajat Keasaman (pH) menggunakan pH Meter.

Adijuwono. 1992. Managemen Laboratorium. Bandung : IPB.

Hardjono. 2001. Kimia Dasar. Yogyakarta : UGM Press.

Lubis, M. 1993. Pengelolaan Laboratorium IPA. Jakarta : Depdikbud

Qomariyah, N. 2004. Uji Derajat Keasaman (pH), Kelarutan, Kerapatan dan Sudut

Tumpukan untuk Mengetahui Kualitas Bahan Pakan Sumber Protein. Volume

78,35 . 
Rusbiono,Momo.2004. Modul Pengadministrasian Alat dan Bahan Sains. Jakarta : Dikmenjur.

Supriatna,Mamat. 2011. Studi Penelusuran Pengelolaan Laboratorium Sains Sebagai Analisis Kebutuhan Untuk Program Diklat Pengelola Laboratorium. Bandung : Widyaiswara P4TK IPA.

Suyanta. 2010. Jurnal Manajemen Operasional Laboratorium. Yogyakarta : UNY 